\title{
Copper metabolism in milch cows I. A proposed method of liver measurement after injection of radio-copper
}

\author{
W. TJ. BINNERTS
}

Laboratory of Animal Physiology, Agricultural University, Wageningen, Netherlands

\section{Summary}

A method is described for the external liver measurement of $64 \mathrm{Cu}$ in (milch) cows after intravenous or intramuscular administration. Radioactive uptake and biological half-life of the liver copper were determined. Some preliminary results are discussed, mainly from the methodological viewpoint.

\section{Introduction}

Numerous investigations relating to the copper status of ruminants, especially cows, are described in the literature. Since the early work of Brouwer et al. (1938) in the Netherlands, the following observations have been made. Copper-deficiency symptoms ${ }^{1}$ appear in summer during the grazing season and are accompanied by low blood- and liver-copper contents. Administration of copper salts will easily cure the disease, but hay feeding during the winter season will also cause the symptoms to disappear spontaneously, even when hay is supplied from "deficient" pastures. Chemical analysis shows that the pasture in copper-deficiency areas is generally poor in copper, but in some regions moderate to high copper contents may even occur without accompanying abnormal molybdenum contents. Another remarkable fact is that low to very low copper values are sometimes found in the blood serum of apparently unaffected animals.

Information on the copper status of cows can be gained by determining copper in blood serum (plasma), red blood corpuscles and liver after autopsy or biopsy. An accurate and complete balance between copper intake and excretion is hardly obtainable by means of metabolism stalls. In special cases hair, urine and milk samples may be analysed. Apart from the balance studies, which are difficult to carry out, it was felt that certain drawbacks attach to these methods. Compared with the results of previous experimentation, the best they can do is to indicate shifts in metabolism, but this requires much time. Radioactivity measurements (Comar et al., 1948) are known to provide a direct and complete insight into the dynamic aspects of the metabolism, and the object of this paper is to investigate the possibility of external measurement of the gamma rays from radioactive liver copper. The isotope available is ${ }^{84} \mathrm{Cu}$ which has a half-life of $12,8 \mathrm{hrs}$ and emits $\beta$ - and $\gamma$-rays. The short half-life

1 For a description of these symptoms see BROUWER et al. (1938), BIJKERK (1949), HOFSTRA (1962), GRIFT (1955) and HARTMANS $(1960,1962)$.

Received for publication 30th May, 1964. 
precludes experiments of longer duration than about $120 \mathrm{hrs}$, but it is also an advantage, since fairly high doses can be administered without harm to the animals and with limited contamination hazards (see No. II of this series).

\section{The liver-copper metabolism}

The liver is considered to be the main storage place of reserve copper, although it is known that some specific enzymes contained in the liver will also incorporate copper for direct use. It is known that "inorganic" copper is constantly withdrawn from the blood, deposited in the liver and incorporated in "organic" protein copper, part of which is subsequently returned to the blood. A constant drain is also exerted via gall-copper excretion, but the exact origin and fate of this copper is not properly understood. Possibly the blood-copper protein, after being chemically modified in its peripheral function, is transported back to the liver and excreted via the bile.

Besides these more or less specific functions, the liver also deals with colloidal copper indiscriminately by filtering it with other colloids in the reticulo-endothelial system (Kupffer cells). Normally these cells are not rich in copper (WACHSTEIN, 1963). For the purpose of the present study the liver functions may be considered as consisting of two main phases, viz. accumulation and discharge. The discharge function in particular is known to be under hormonal control. The incorporation of administered copper in the specific blood protein can be appreciably accelerated by ethinyl estradiol (RUSS and RAYMUNT, 1956).

\section{The liver measurement in vivo}

The most satisfactory conditions for measuring the gamma rays would be at a considerable distance from the radio-copper source relative to the dimensions of that source. Unfortunately the liver is a large organ, especially in cows, and measurement at a distance of $1 \mathrm{~m}$ or more would require an exceptionally large dose of radioactivity. Some compromise must therefore be accepted. In principle two methods could be used 1. with the scintillation crystal uncollimated and placed in direct contact with the skin overlying the liver, 2 . with the crystal at a fixed distance from the skin, using a wide-angle collimator. The first method will permit the use of smaller quantities of radioactivity, but not all parts of the liver will be "seen". The second method, which requires a little more radioactivity, will do more justice to the whole liver, and interference from other body copper may be reduced by choosing a fairly short distance (about $20 \mathrm{~cm}$ ).

It may be noted that by applying both methods simultaneously and comparing the results an insight can be gained as to the shape and dimensions of the liver, although in normal cows of comparable size the ratios will not differ by any considerable extent. This technique will be reserved for pathological conditions.

In both cases, and especially when the counter is applied direct to the skin, the following precautions should be taken. Either the exact location should be marked for further measurements, or one should ensure that readings are only taken at the site of maximum activity. A thin $(1 \mathrm{~mm})$ lead shield should be placed in front of the crystal in order to eliminate most of the difference of background readings directly above the animal and in the atmosphere.

These methods are used together with injection. After oral administration special

Neth. J. agric. Sci., Vol. 12 (1964) No. 4 (November) 
procedures should be used to prevent interference from the copper in the gastrointestinal tract.

\section{Some preliminary results}

Following intravenous injection, the radio-copper is rapidly taken up. This is shown by the liver and blood counts to the left of FIG. 1. The solution of radio-copper (pH $-4,5$, as the nitrate, volume ca. $4 \mathrm{ml}$, spec.act. $0,05-0,2 \mathrm{mc} / \mathrm{mg}$ ) was injected in about $1 \mathrm{~min}$. into the jugular vein and the blood samples were taken from the jugularis at the opposite side of the animal. For the liver measurements the distance was reproduced by using on the counter a fixed length of extension in contact with the skin, and the exact location was marked by clipping the hair. The readings in FIG. 1 were taken once, unlike the normal measurements which consisted of three separate, independent readings. The results were corrected for background in the

FIG. 1. Radioactivity observed in liver and blood serum after intravenous injection of radio-copper
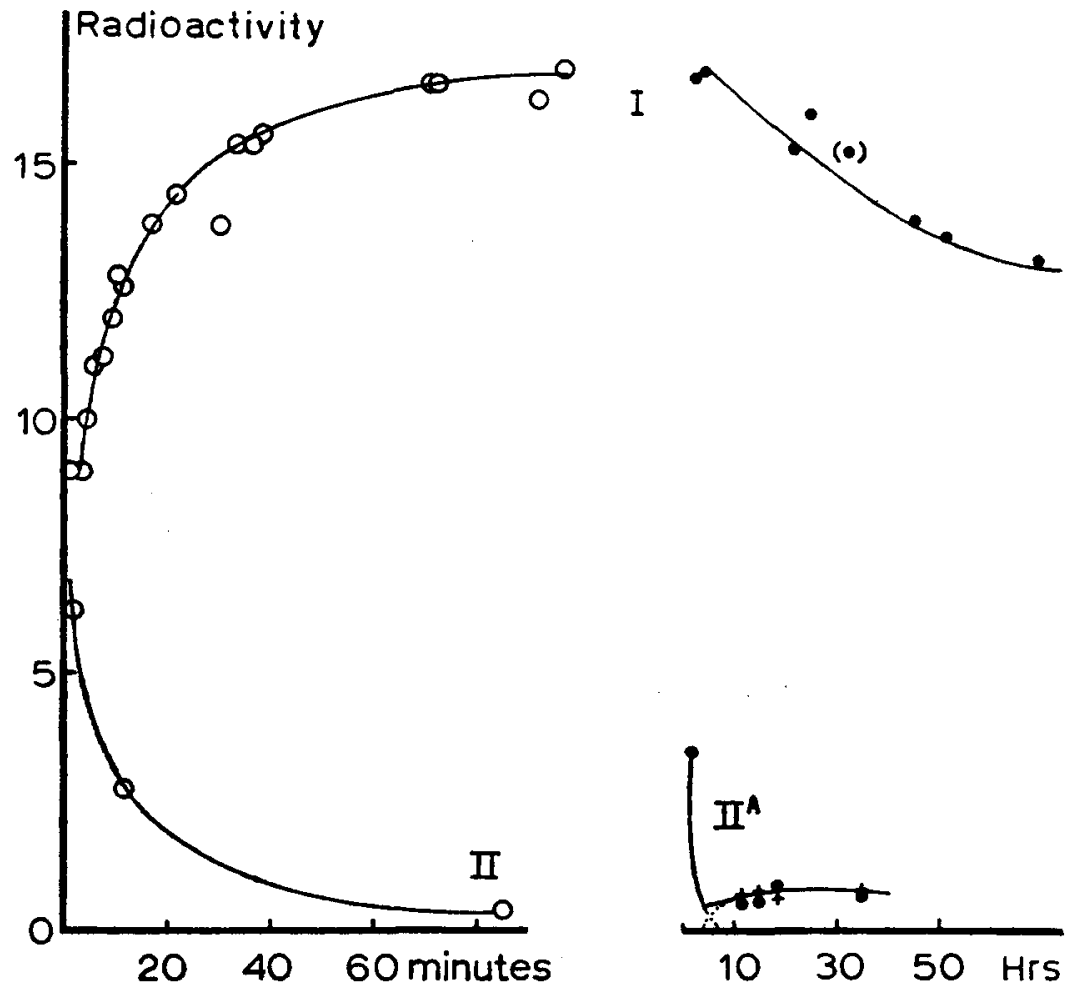

\section{Liver II Blood serum (in $\Pi^{\wedge} 10 x$ )}


same manner as in all other experiments, but the immediate onset of radioactivity in the first minute shows that the blood in the liver and the large neighbouring vessels makes an appreciable contribution. After a few hours this interference diminishes rapidly with the blood radioactivity to an insignificant level. The subsequent discharge from the liver can be seen on the right on the same figure; this process can be very satisfactorily described by a logarithmic relationship with time, as illustrated in the other graphs. The figure also shows the activity of the blood copper; after the practical disappearance of the original dose of inorganic copper, a maximum level seems to be attained, presumably after the build-up of protein copper.

FIG. 2 shows the discharge function of the liver in three experiments. In the first, performed during winter, the two comparable cows were on the same ration, one receiving $1 \mathrm{~g}$ of additional $\mathrm{CuSO}_{4} .5 \mathrm{H}_{2} \mathrm{O}$ per day. They were given intravenous doses of radio-copper. The discharge, as will be seen from the figure, was fairly rapid, the biological half-life $(t 1 / 2)$ being of the order of a few days. Contrariwise, in the second experiment, conducted in summer, the secretion rate in all four cows tended to be low ( $t \frac{1}{2} \cong 1000 \mathrm{hrs}$ ) (for the sake of simplicity only two, Z9 and W7, are shown

Fig. 2. Secretion of radioactive copper from liver. Cows $A 8$ and $N 7$ were used in the first experiment, W7 and $\mathrm{Z9}$ (upper line) in the second (summer) and W7, Z9 (bottom) and B2 in the third experiment with oral administration

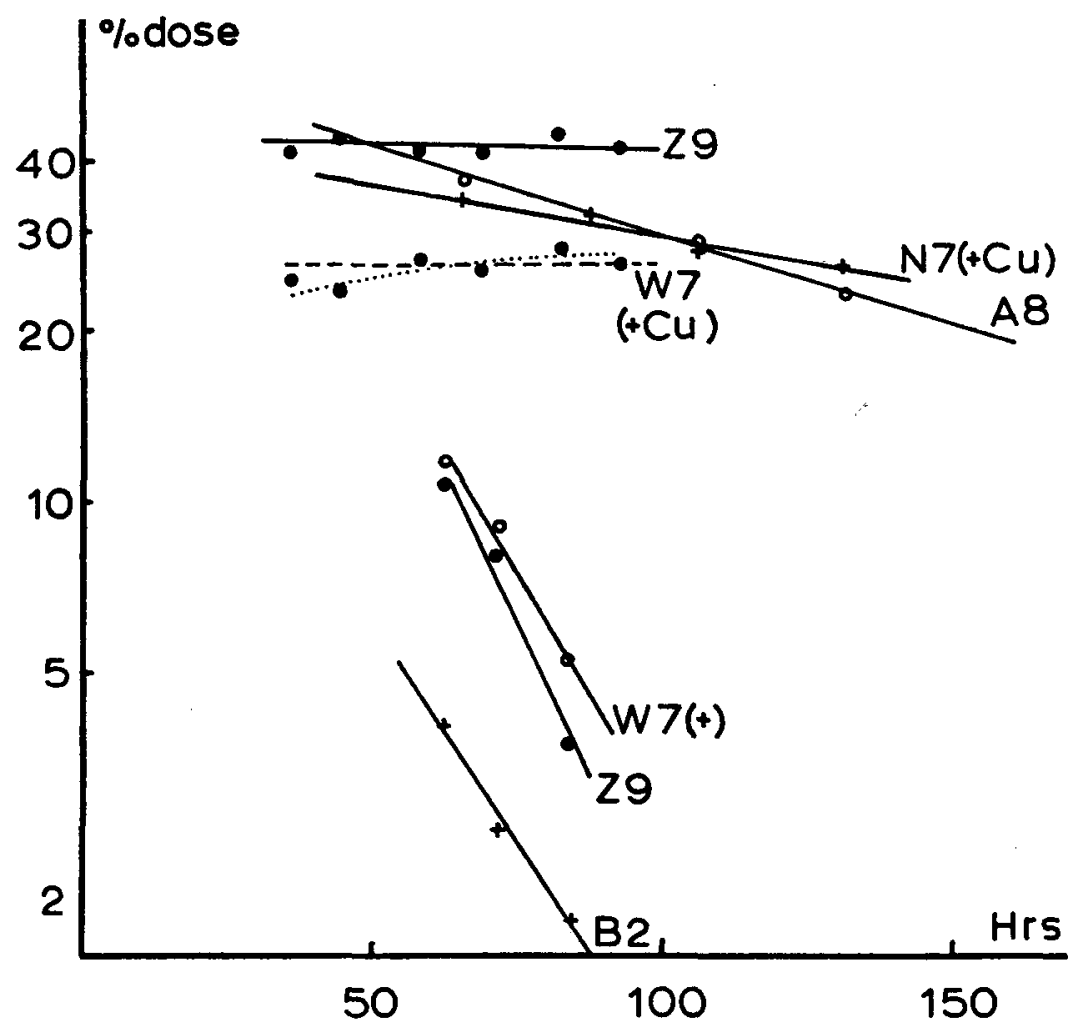

Neth. J. agric. Sci., Vol. 12 (1964) No. 4 (November) 
in the graph). Again in comparable pairs of animals one animal was dosed with $1 \mathrm{~g}$ of copper sulphate daily. The third experiment with oral administration is merely given as an illustration of contrasting results in the lower part of FIG. 2, viz. the extremely steep lines are probably due to interference by intestinal radio-copper, even $72 \mathrm{hrs}$ after dosing. These measurements will not be considered here as they are discussed in a separate communication.

One further important question is whether the injected radio-copper behaves in the same way as the copper from the feed and the drinking water. Schultze et al. (1934) have shown in experiments with copper-deficient rats that nearly all copper compounds behave in the same way when given orally. Only porphyrin and sulfide copper was not readily available, but even the sulphur-bound copper in cysteine was equivalent to the other readily absorbable compounds. For non-deficient ruminants however, LAssiter and Bell (1960) and Chapman and Bell (1963) recently reported appreciable differences in the uptake of different copper salts after oral administration. In intravenous administration, as in the present experiment, an additional difficulty seems to be the possibility of hydrolysis of the copper salts at the pH of blood and the subsequent formation of colloidal particles; in fact, a slight flocculation is always observed after the injection when the syringe is washed with freshly drawn blood. As stated in a preceding paragraph, any colloidal copper would behave in the same way as the larger particles that are filtered in the reticulo endothelial cells of the liver. It is conceivable that the radio-copper isolated by these cells will not be in ready equilibrium with the normal liver-copper reserve. A number of experiments were therefore devised of which some results are given in FIG. 3 .

In this case the radio-copper was injected intravenously, intramuscularly or subcutaneously and both the liver and the injection site was monitored. Probably owing to the small quantity of carrier copper injected (ca. $5 \mathrm{mg}$ ), the radioactivity was transported fairly rapidly through the body, and it was only after subsutaneous dosage that the liver quantities had to be corrected for the percentage of unassimilated copper.

The experimental material is a good means of distinguishing from the extremely rapid discharge after oral administration, as shown in FIG. 2. It may also be assumed that the liver makes no appreciable distinction between the copper supplied by different routes of injection, so that special effects like those discussed earlier will not have occured after intravenous injection. An additional experiment with intravenous injection of the copper in the form of a glycine complex resulted in about the same half-lives as in the preceding and following experiment, although the copper seemed to be taken up more readily.

The results of this and other experiments are summarised in the TABLE. Although the results are provisional and should be substantiated by more extensive material, the following conclusions can be made regarding the usefulness of the method.

The half-life of the liver copper in summer (data in bold print) shows a distinct trend towards lower values with time; the first, second and fourth column relate to the same three animals; the animal in the third column went dry after the August experiment and had to be replaced by a comparable cow. The copper supplement had no appreciable effect on the half-lives but caused a definite reduction in the percentage uptake. The differences between summer and winter results are interesting and partly unexpected, but they are no reason for doubting the applicability of the method; the physiological implications will be discussed elsewhere.

The last row in the table gives some results of experiments performed on a different 


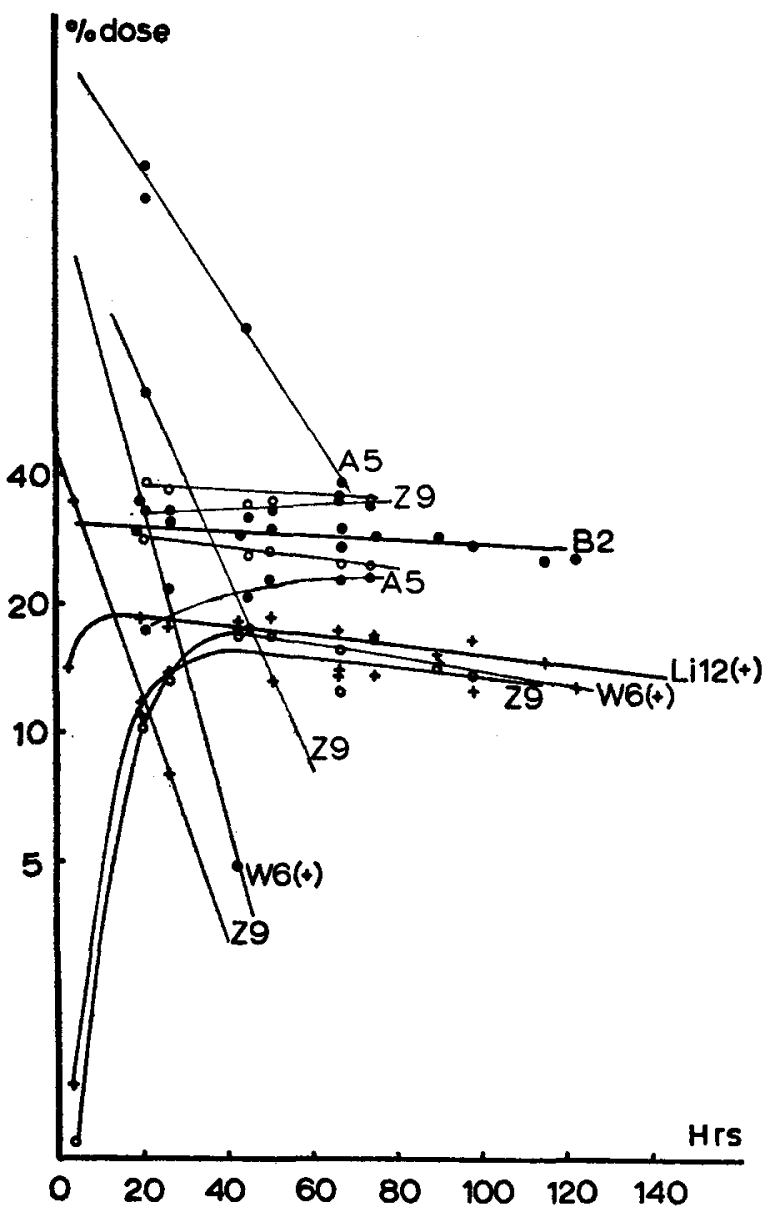

FIG. 3

Liver readings following varying forms of ${ }^{64} \mathrm{Cu}$-administration, viz. cows $\mathrm{B} 2$ and $\mathrm{Li} 12$ intravenous, W6 and $Z 9$ (middle) intramuscular, Z9 (upper line) and A5 (middle) subcutaneous. In the subcutaneous experiment the corrected values are represented by white circles. For the purpose of correction the steeply descending lines are drawn to connect observations at the site of the injection, the two higher lines representing subcutaneous administration and the two lower lines intramuscular administration.

TABLE. Biological half-life and maximum uptake in liver

\begin{tabular}{|c|c|c|c|c|c|c|c|c|}
\hline Month & & $\mathrm{Hal}$ & -life (hrs) & & Maxim & n upta & ke ("\% & dose") \\
\hline $\begin{array}{l}\text { March } \quad \ldots \ldots \ldots \ldots \ldots \\
\text { Aug. } \quad \ldots \ldots \ldots \ldots \\
\text { Sept. (glycine) } \ldots \ldots \ldots \ldots \\
\text { Oct. } \quad \ldots \ldots \ldots \ldots \ldots \\
\text { Dec. } \quad \ldots \ldots \ldots \ldots \ldots \ldots \\
\text { Jan. } \quad \ldots \ldots \ldots \ldots \ldots \ldots \\
\end{array}$ & $\begin{array}{r}100 \\
2000 \\
1000 \\
470 \\
390 \\
510\end{array}$ & $\begin{array}{r}1100 \\
500 \\
260 \\
295 \\
185\end{array}$ & $\begin{array}{l}170(+) \\
2000(+) \\
500(+) \\
200(+) \\
140^{*} \\
200^{*}\end{array}$ & $\begin{array}{l}425(+) \\
450(+) \\
240(+) \\
230^{*} \\
310^{*}\end{array}$ & $\begin{array}{l}61 \\
29,5 \\
40 \\
31 \\
52 \\
39\end{array}$ & $\begin{array}{l}36 \\
40,5 \\
17 \\
45,5 \\
40\end{array}$ & $\begin{array}{l}44(+) \\
22(+) \\
36(+) \\
19(+) \\
45^{*} \\
30^{*}\end{array}$ & $\begin{array}{l}28(+) \\
36(+) \\
20(+) \\
40^{*} \\
23^{*}\end{array}$ \\
\hline $\begin{array}{l}\text { Cows' names } \ldots \ldots \ldots \ldots \\
\text { Nov. } \quad \ldots \ldots \ldots \ldots \ldots \ldots\end{array}$ & $\begin{array}{r}\text { A4 } \\
1260\end{array}$ & $\begin{array}{r}\text { A5 } \\
1700\end{array}$ & $\begin{array}{r}\text { A21 } \\
350\end{array}$ & $\begin{array}{r}\text { A22 } \\
140\end{array}$ & $\begin{array}{r}\text { A4 } \\
34\end{array}$ & $\begin{array}{r}\text { A5 } \\
29\end{array}$ & $\begin{array}{r}\mathrm{A} 21 \\
25\end{array}$ & $\begin{array}{l}\text { A22 } \\
21\end{array}$ \\
\hline
\end{tabular}

1 These values have no absolute significance since it was impossible to construct individual liver phantoms.

* The dosed cows ( $1 \mathrm{gm}$ of copper sulphate a day) are marked $(+)$; figures in bold print refer to outdoor experiments, asterisks to dry cows. 
farm. Here the animals were at pasture, although for the last week. Two of them (A4 and A5), identical twins, were relatively small animals $(440 \mathrm{~kg}$ ) and had normal serum-copper contents of about $1 \mathrm{mg} / \mathrm{kg}$. The other two (A21 and A22), also identical twins, were larger $(550 \mathrm{~kg})$ and had low serum-copper contents of approx. $0,1 \mathrm{mg} / \mathrm{kg}$. The results in each twin were not expected to be identical as they had been subjected to other experiments before (not with copper). Nevertheless, it was noted that the two larger animals showed a distinctly lower half-life of the liver copper than the two smaller animals. It seems that the latter twins are protected from hypocupremia by an efficient liver control; they also have a higher liver count, but this can be partly explained by difference in geometry. The larger animals had a fairly low liver uptake compared with the animals of the previous experiments. This, together with the short half-life in these twins, seems to be evidence of a more careless copper utilization. It is realised that additional blood analyses will be useful as a complement to the proposed method.

\section{ACKNOWLEDGEMENTS}

My thanks are due to R.C.N. (Reactor Centre Netherlands), Petten; ITAL (Institute for Atomic Sciences in Agriculture), Wageningen, and to Philips-Duphar, Amsterdam, for their co-operation in the preparation and supply of the radio-copper, to Prof. Dr. Th. DE Groot, for kind permission to work with the identical twins, and to Drs. A. Th. van 'T Klooster, J. H. AafJes, J. van den Hoek (ITAL, Wageningen) and $H$. Jonker (Vaassen) for the injections.

Brouwer, E., A. M. Frens, P. ReITsma and C. Kalisvaart BIJKerk, R.

Chapman, H. L., and M. C. BELL

Comar, C. L., G. K. Davis and L. Singer GRIFT, J. VAN DER

Hartmans, J.

Hofstra, S. T.

LASSITER, J. W., and M. C. BELL

Russ, E. M., and

T. RAYMUNT

\section{REFERENCES}

1938 Onderzoekingen over de z.g. diarrhoeweiden ("scouring pastures") in den Wieringermeerpolder. Versl. Wet. Landbk. Onderz. 44(4)C, 267-298.

1949 Oriënterend onderzoek omtrent de koperstofwisseling van gezonde en zieke paarden en runderen in verband met het gehalte aan koper in de lever. Thesis. Utrecht, 1949. $130 \mathrm{pp}$. + appendices.

1963 Relative absorption and excretion by beef cattle of copper from various sources. J. Anim. Sci. 22, 82-85.

1948 The fate of radioactive copper administered to the bovine. J. Biol. Chem. 174, 905-914.

1955 Het kopergehalte van lever en bloedserum. Thesis. Utrecht, $1955.63 \mathrm{pp}$.

1960 Waarnemingen over koperverlies bij weidend jongvee in Friesland. Jaarb. I.B.S. 1960. 143-154.

1962 Kopergebrek en klinische verschijnselen bij het rund, mede in verband met de ontwikkeling van het dier en met de waterhuishouding van de bovengrond. Jaarb. I.B.S. 1962. 157-166.

1952 Weidediarrhee bij het rund op laagveengrond in het Zuidwesten van Friesland. Thesis. Utrecht, 1952. 238 pp. + appendices.

1960 Availability of copper to sheep from Cu-64 labeled inorganic compounds. J. Anim. Sci. 19, 754-762.

1956 Influence of estrogens on total serum copper and caeruloplasmin. Proc. Soc. Exptl. Biol. Med. 92, 465-466. 
SChUL TZE, M. O., C. A. Elvehiem and E. B. Hart

SCHULTZE, M. O., C. A. ElvehJem and E. B. HART

WACHSTEIN, M.
1934 The availability of copper in various compounds as a supplement to iron in hemoglobin formation. J. Biol. Chem. 106, 735-744.

1936 Further studies on the availability of copper from various sources as a supplement to iron in hemoglobin formation. J. Biol. Chem. 115, 453-457.

1963 Cyto- and histochemistry of the liver. In The Liver. l, 149 (Ch. Rouiller ed.) Acad. Press, New York-London. 